\title{
Pengaruh Pemberian Mikroemulsi Limbah Minyak Terhadap Kandungan ASAM LEMAK OMEGA-3 DIDALAM TELUR
}

\author{
The Influence of WAste Oil Microemulsion on ACIDS CONTENT OF OMEGA-3 \\ FATTY IN EGGS \\ ${ }^{1}$ Indra T. Maulana, ${ }^{2}$ Reyhan G, ${ }^{3}$ Sani Ega P, ${ }^{4}$ Reza A.K. \\ ${ }^{1,2,3,4}$ Fakultas MIPA Universitas Islam Bandung \\ e-mail : ${ }^{1}$ indra.topik@gmail.com
}

\begin{abstract}
Egg is one of the farm product that the most consumed by the public. The eggs are very easy to obtain and the price is cheap that makes it affordable by all people. Eggs can be converted into a functional food by providing a chicken as a source of eggs for the provision of rations plus treatment with fish oil microemulsion waste. Waste fish oil formerly is purified before it is being made provision. The analysis results of fatty acid content in eggs with GCMS shows that the eggs produced by the chickens given the microemulsion contains omega-3 is higher than the result from eggs produced by the chickens who were just given rations and concentrates without artificial microemulsion
\end{abstract}

Keywords: eggs, omega -3, microemulsion, fatty acids.

\begin{abstract}
Abstrak. Telur ayam merupakan salah satu produk peternakan yang paling banyak dikonsumsi oleh masyarakat. Telur sangat mudah diperoleh dan harganya murah sehingga terjangkau oleh seluruh kalangan masyarakat. Telur dapat diubah menjadi pangan fungsional dengan cara memberikan ayam ras sebagai sumber telur perlakuan berupa pemberian ransum ditambah dengan sediaan mikroemulsi limbah minyak ikan. Limbah minyak ikan terlebih dahulu dimurnikan sebelum dijadikan sediaan. Hasil analisa kandungan asam lemak didalam telur dengan GCMS menunjukkan bahwa telur yang dihasilkan oleh ayam yang diberikan sediaan mikroemulsi memiliki kandungan omega-3 jauh lebih tinggi dibandingkan telur yang dihasilkan oleh ayam yang hanya diberikan ransum dan konsentrat tanpa dibuat sediaan mikroemulsi
\end{abstract}

Kata Kunci : telur, omega-3, mikroemulsi, asam lemak.

\section{Pendahuluan}

Pangan Fungsional (fungtional food) saat ini telah menjadi pilihan bagi sebagian masyarakat penderita penyakit degeneratif dan metabolik dalam mengontrol menu diet sehari - hari. Pangan fungsional dipilih karena bentuknya yang berupa makanan, namun nutrisi didalamnya telah mengalami proses fortifikasi yang mendukung kondisi kesehatan pengguna. Saat ini pangan fungsional yang banyak dikonsumsi oleh sebagian masyarakat adalah produk susu. Produk susu merupakan produk pangan yang mudah difortifikasi terutama dengan nutrisi yang dibutuhkan oleh penderita penyakit degeneratif dan metabolik. 
Telur ayam merupakan sumber protein hewani yang paling banyak digemari oleh masyarakat Indonesia. Hal ini terbukti melalui hasil survei badan pusat statistika yang menyatakan bahwa pada tahun 2014 rata - rata konsumsi telur per kapita selama satu minggu adalah sebanyak $0,171 \mathrm{~kg}$ atau sekitar 3,42 butir telur (dengan asumsi satu telur bobot rata-rata $50 \mathrm{mg}$ ). Angka ini jauh lebih tinggi dibandingkan konsumsi telur itik/asin yang hanya 0,047 butir per minggu. Besaran kapita konsumsi telur juga mengalahkan besaran konsumsi daging baik ayam atau sapi, tahu, bahkan tempe. Kondisi ini memperlihatkan bahwa telur telah dikenal luas oleh masyarakat Indonesia, selain karena harganya yang murah, proses memasak yang mudah, telur juga tersedia setiap saat dan mudah diperoleh.

Telur memiliki peluang untuk dijadikan sebagai salah satu komoditas pangan fungsional yang murah, mudah diperoleh dan tersedia setiap saat. Berbeda halnya dengan susu, telur lebih dikenal oleh seluruh lapisan masyarakat. Namun untuk menjadikan telur sebagai salah satu pangan fungsional memerlukan teknik khusus. Pada umumnya, telur ayam kaya akan kolesterol, asam lemak jenuh namun rendah akan asam lemak tak jenuh. Konsumsi telur yang banyak mengandung asam lemak jenuh dan kolesterol dapat menimbulkan dampak buruk bagi kesehatan. Untuk menjadikan telur sebagai sebuah pangan fungsional, maka perlu dilakukan sebuah penanganan sehingga menjadikan telur kaya akan asam lemak tak jenuh omega-3 namun rendah akan kandungan asam lemak jenuh dan kolesterol.

Mengkonsumsi telur yang kaya akan asam lemak tak jenuh terutama omega-3 khususnya EPA dan DHA mampu memberikan manfaat bagi kesehatan khususnya mencegah resiko penyakit jantung koroner. Konsumsi EPA dan DHA dalam jangka waktu panjang terbukti memiliki dampak positif terhadap penderita penyakit jantung koroner, yaitu mampu menurunkan resiko kematian mendadak hingga $45 \%$ jika dibandingkan terhadap penderita yang tidak mengkonsumsi EPA dan DHA (Haris, 2004). EPA dan DHA juga bermanfaat terhadap penyembuhan gejala keloid (Olaitan dkk, 2011), menurunkan kolesterol dalam darah khususnya LDL, anti agregasi platelet, dan anti inflamasi (Haris, 2004). Berdasarkan Pengujian produk telur sebagai pangan fungsional terhadap penderita penyakit kardiovaskular ternyata, telur tersebut mampu menurunkan secara signifikan kadar trigliserida didalam plasma sebesar $32 \%$, menurunkan rasio TAGs : HDL $37 \%$, serta mampu menurunkan tekanan darah pasien (Rose \& Holub, 2006). Telur yang kaya akan EPA dan DHA mampu menurunkan kadar LDL dan meningkatkan HDL didalam darah (Butarbutar, 2004).

Adapun salah satu teknik yang dilakukan untuk menjadikan telur sebagai pangan fungsional adalah dengan mencampurkan ransum dengan limbah minyak ikan. Berdasarkan penelitian Cachaldora dkk (2005), Ayam yang diberikan minyak ikan mampu menghasilkan telur yang lebih kaya asam lemak omega-3 dibandingkan dengan ayam yang diberikan minyak biji matahari. Di Indonesia, Limbah minyak yang digunakan oleh para peternak sebenarnya merupakan limbah industri pengolahan ikan yang berada di daerah Muncar, Banyuwangi (Maulana, 2013).

Limbah minyak ikan yang diperoleh dari Banyuwangi diketahui mengandung asam lemak omega-3 dalam jumlah cukup melimpah, namun disamping itu limbah 
minyak tersebut juga mengandung asam lemak jenuh dan asam elaidat dalam jumlah yang sangat dominan (Maulana, 2014). Asam lemak jenuh merupakan asam lemak yang tidak memiliki ikatan rangkap dan berupa rantai karbon yang cukup panjang. Apabila dikonsumsi maka berdampak pada peningkatan trigliserida didalam tubuh. Sedangkan asam elaidat merupakan jenis asam lemak trans yang berbahaya apabila dikonsumsi oleh manusia. Asam lemak trans (trans Fatty Acid/tFA) dapat meningkatkan resiko penyakit jantung koroner melalui stimulasi faktor penyebabnya seperti peningkatan rasio kolesterol total terhadap HDL, peningkatan jumlah LDL, memperkecil ukuran partikel LDL dan meningkatkan kolesterol total dalam darah (Mozaffarian dkk, 2006; Stender \& Dyerberg, 2003). Disamping itu, $t$ FA juga terbukti berkaitan erat dengan kanker payudara dan diabetes melitus tipe 2 (Stender \& Dyerberg, 2003; SACN, 2007).

Bahan minyak ikan yang mengandung asam lemak jenuh dan asam elaidat apabila diberikan terhadap ayam petelor akan berpotensi menghasilkan telur yang mengandung kolesterol, trigliserida, dan asam lemak trans. Dampaknya adalah telur yang dikonsumsi akan menyebabkan timbulnya penyakit bagi manusia. Oleh karena itu, limbah minyak sebelum digunakan terlebih dahulu perlu dimurnikan dari kandungan asam lemak jenuh dan asam lemak trans.

Untuk menjaga kestabilan dari konsentrat asam lemak, maka bahan dibuat menjadi sediaan farmasi berupa sediaan mikroemulsi. Sediaan mikroemulsi tipe minyak dalam air ini selain diharapkan mampu melindungi konsentrat asam lemak juga untuk meningkatkan efektifitas kinerja konsentrat terhadap telur ayam.

\section{Metode Penelitian}

\subsection{Alat dan Bahan}

Bahan yang digunakan adalah minyak ikan limbah dari Muncar Banyuwangi, etanol, asam asetat glasial, kloroform, $\mathrm{KI}, \mathrm{Na}_{2} \mathrm{~S}_{2} \mathrm{O}_{3}, \mathrm{NaOH}$, n-heksan, $\mathrm{HCl}$, urea, alfa tokoferol, metanol, etil asetat, surfaktan (tween 20), sorbitol, dan gliserin. Sedangkan alat yang digunakan meliputi Erlenmeyer, buret, gelas kimia, sentrifuga, vial, Corong Buchner, freezer, timbangan analitik, labu refluks tiga mulut, penangas parafin, magnetik heater stirrer, Shimadzu QP 2010 ULTRA dengan detektor FID. Kolom RTX-5 (difenil dimetilpolisiloksan, panjang $30 \mathrm{~m}$, diameter 0,25 mm).

\subsection{Metode}

Minyak limbah sebelum digunakan terlebih dahulu dianalisis kandungan asam lemaknya dengan menggunakan instrumen Kromatografi Gas - Spektroskopi Massa (KG - SM). Minyak kemudian dimurnikan hingga diperoleh sehingga diperoleh minyak murni. Minyak murni selanjutnya dihidrolisis dengan metode penyabunan (saponifikasi) menjadi asam lemak. Senyawa tidak tersabunkan (jika ada) dihilangkan dengan penambahan nheksana. Campuran berupa sabun selanjutnya diasamkan kemudian ditambahkan nheksana guna menarik asam lemak.

Asam lemak selanjutnya difraksinasi dengan teknik kristalisasi menggunakan larutan urea panas sehingga diperoleh konsentrat berupa cairan berwarna kuning jingga. 
Konsentrat yang diperoleh kemudian didinginkan kembali pada suhu $4{ }^{\circ} \mathrm{C}$ untuk menghilangkan urea yang masih terbawa. Selanjutnya konsentrat dibuat menjadi sediaan mikroemulsi dengan menggunakan komposisi bahan gliserin $5 \%$, sorbitol 15 $\%$, serta tween 20 sebesar $40 \%$. Adapun kekuatan sediaan dalam setiap $5 \mathrm{~mL}$ sediaan mengandung $100 \mathrm{mg}$ konsentrat sebagaimana dibuat oleh Jufri dkk (2009). Sediaan mikroemulsi yang dihasilkan kemudian dikemas dalam wadah vial berukuran $5 \mathrm{~mL}$ tertutup rapat, dan disimpan pada suhu kamar terlindungi dari cahaya matahari.

Penelitian ini menggunakan tiga kelompok ayam ras petelor didalam kandang, yang mana pada setiap kandang terdapat lima ekor ayam. Adapun kepada Kelompok pertama, diberikan ransum tanpa ditambahkan sediaan konsentrat (kelompok ini dijadikan sebagai kontrol), kelompok kedua diberikan ransum yang dicampurkan dengan sediaan mikroemulsi, kelompok ketiga diberikan ransum yang dicampurkan dengan konsentrat langsung (tidak dalam bentuk sediaan mikroemulsi). Ayam yang dipilih pada setiap kelompok adalah yang telah berusia 38 minggu (siap bertelur) sesuai dengan yang dilakukan pada penelitian Cacholdora dkk (2005). Setiap kelompok ayam ditempatkan pada kandang berbeda, kemudian selama 21 hari pertama ayam diberikan perlakuan praeksperimental dengan memberikan pakan saja. Berikutnya, kepada semua kelompok ayam selama 28 hari berturut - turut diberikan perlakuan eksperimental sesuai dengan masing-masing kelompok ayam. Berdasarkan hasil penelitian Chamruspollert \& Sell (1999) dalam Cacholdora dkk (2005) dinyatakan efek pemberian asam lemak terhadap ayam maksimum akan muncul sekitar $10-11$ hari setelah pemberian.

Setiap telur yang dihasilkan kemudian dianalisis kandungan asam lemaknya menggunakan GCMS Shimadzu QP 2010 ULTRA dengan detektor FID. Kolom yang digunakan adalah RTX-5 (difenil dimetilpolisiloksan sebagai padatan penyangga, panjang $30 \mathrm{~m}$, diameter $0,25 \mathrm{~mm}$ ). Suhu injektor diatur $240{ }^{\circ} \mathrm{C}$, suhu detektor $280{ }^{\circ} \mathrm{C}$, dengan gas He sebagai pembawa. Suhu kolom awal diatur $140{ }^{\circ} \mathrm{C}$ ditahan selama 2 menit, kemudian dinaikkan dengan laju konstan $4{ }^{\circ} \mathrm{C} /$ menit hingga dicapai suhu 260 ${ }^{\mathrm{O}} \mathrm{C}$ yang kemudian ditahan selama 2 menit. Jadi total lamanya waktu analisis dengan KGSM adalah 34 menit

\section{Hasil dan Pembahasan}

\subsection{Analisis Kandungan Asam Lemak dalam Limbah}

Limbah minyak yang digunakan terlihat berwarna coklat gelap, berbau tengik, dan buram (tidak bening). Hasil analisis GCMS terhadap bahan dapat dilihat pada gambar 1, dimana pada gambar tersebut menunjukkan bahwa limbah minyak mengandung asam lemak yang sangat penting seperti EPA, DHA, CLA, dan asam Oleat. Namun, disamping itu juga didalam limbah minyak terdapat kandungan asam lemak trans (Asam 9-oktadesenoat (E)) yang berpengaruh buruk terhadap kesehatan. 


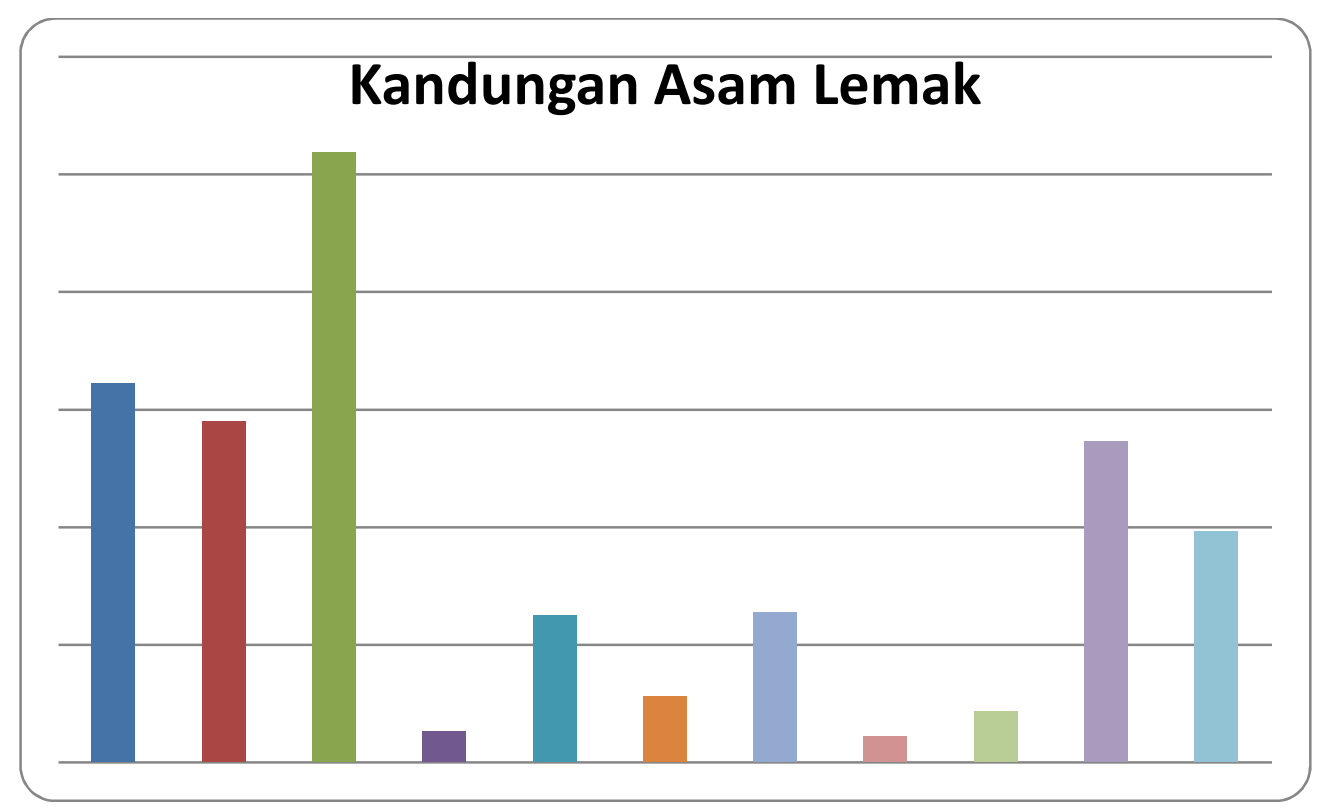

Gambar 1. Kandungan asam lemak dalam limbah minyak

Jika digolongkan berdasarkan jenis omega-nya, maka terlihat jelas bahwa minyak limbah kaya akan kandungan omega-3 yang merupakan asam lemak esensial dan bermanfaat bagi kesehatan. seperti yang terlihat pada gambar 5.2, kelompok omega3 menempati urutan kedua terbanyak setelah asam lemak jenuh. Adanya kandungan asam lemak jenuh dalam jumlah besar, apabila diberikan kedalam pakan langsung maka akan menghasilkan telur yang kaya akan asam lemak jenuh.

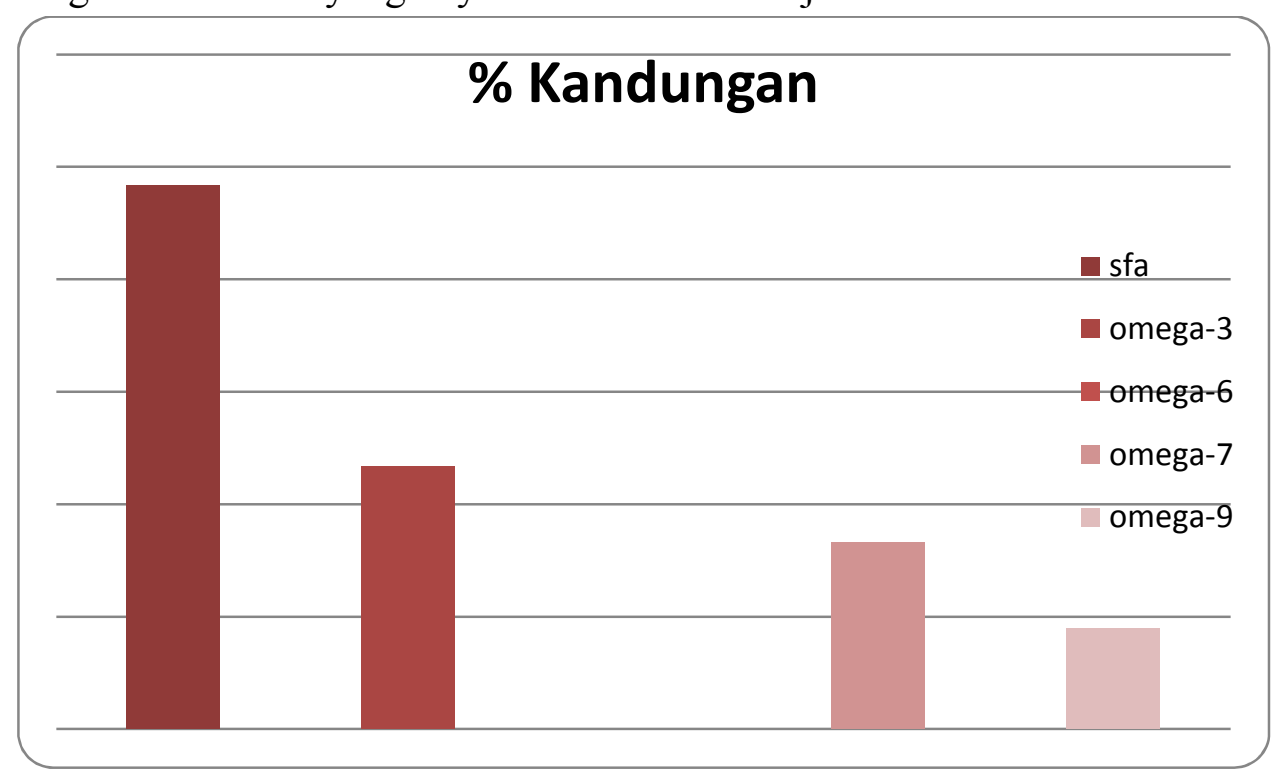

Gambar 2. Kandungan asam lemak didalam limbah minyak berdasarkan jenis omega

Gambar 1. dan gambar 2., ini menunjukkan bahwa minyak limbah masih layak digunakan bahkan dimanfaatkan untuk dijadikan sebuah sediaan mikroemulsi.

1. Pengaruh Pemberian Mikroemulsi terhadap Kandungan Asam Lemak Omega-3 dalam Telur 
Tujuan akhir yang diharapkan dari penelitian ini adalah adanya peningkatan kandungan asam lemak omega-3 didalam telur yang dihasilkan oleh ayam ras yang diberikan perlakuan berupa ransum ditambah dengan sediaan mikroemulsi. Adapun hasil analisis kandungan asam lemak omega-3 didalam telur ikan dapat dilihat pada gambar 3 dan gambar 4.

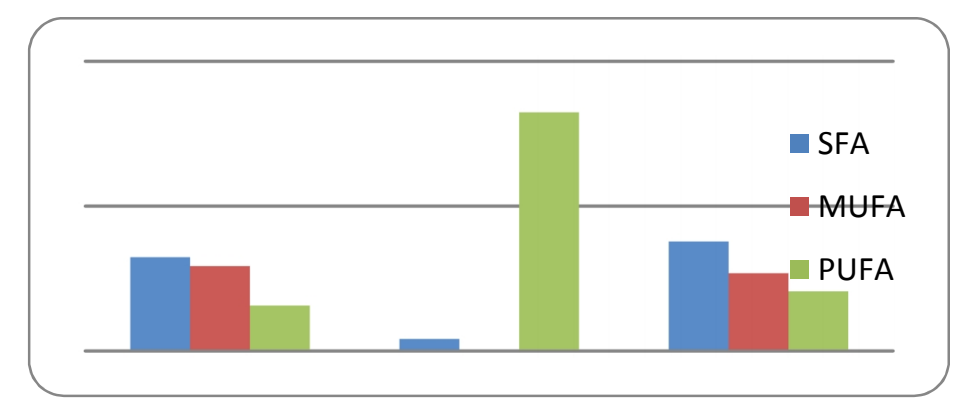

\section{Gambar 3. Grafik perbandingan kandungan golongan asam lemak didalam telur hasil perlakuan}

Keterangan :

Kel. 1 : telur yang dihasilkan oleh ayam yang hanya diberikan ransum

Kel. 2 : telur yang dihasilkan oleh ayam yang diberikan ransum + mikroemulsi

Kel. 3 : telur yang dihasilkan oleh ayam yang diberikan ransum + konsentrat

SFA : Saturated Fatty Acid/ Asam lemak jenuh

MUFA : Mono Unsaturated Fatty Acid / Asam lemak tak jenuh ikatan rangkap tunggal

PUFA : Poly Unsaturated Fatty Acid / Asam lemak tak jenuh ikatan rangkap ganda

Berdasarkan gambar 3., dapat dilihat bahwa telur yang dihasilkan oleh ayam kelompok 2 sangat kaya akan Poly Unsaturated Fatty Acid (PUFA) dimana kondisinya jauh berbeda apabila dibandingkan dengan kelompok 1 dan kelompok 3. Hal ini menunjukkan bahwa sediaan mikroemulsi lebih efektif untuk diserap oleh saluran pencernaan ayam jika dibandingkan dengan bentuk konsentrat. Adanya kandungan asam lemak didalam kelompok 1 kemungkinan merupakan dampak dari penambahan tepung ikan racah pada ransumnya.

Telur kelompok 2 juga mengandung asam lemak jenuh yang sangat rendah jika dibandingkan dengan kelompok satu dan tiga. hal ini secara teori belum dapat dijelaskan dengan pasti, namun ada kemungkinan besar bahwa sediaan mikroemulsi yang lebih cepat dan efektif diserap oleh saluran pencernaan ayam ras mampu mempengaruhi komposisi kandungan kimia dalam kuning telur. Dimana kandungan PUFA menjadi sangat dominan dibandingkan dengan SFA dan MUFA.

PUFA yang dominan terdapat didalam telur ayam kelompok dua adalah Omega3, seperti yang nampak pada gambar 4. Dimana kandungan Omega-3 pada telur kelompok 2 jauh lebih besar dibandingkan pada kelompok 1 dan 3. Hal ini semakin mendukung pernyataan bahwa bentuk sediaan mikroemulsi lebih cepat dan efektif diserap oleh saluran pencernaan ayam dibandingkan dengan dalam bentuk konsentrat. Adapun asam lemak omega-3 yang dominan terdapat didalam telur ayam Kelompok 2 adalah EPA dan DHA. 


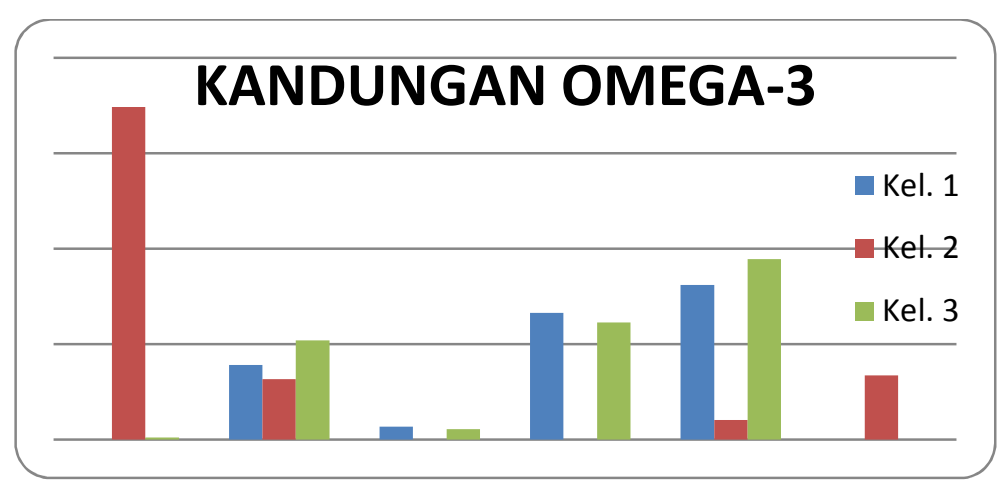

Gambar 4. Grafik perbandingan kandungan golongan omega asam lemak didalam telur hasil perlakuan

\section{Kesimpulan}

Sediaan mikroemulsi saat ditambahkan kedalam ransum (pakan ayam) mampu memberikan pengaruh terhadap peningkatan kandungan asam lemak omega-3 didalam telur. Secara keseluruhan bahwa pembuatan sediaan mikroemulsi konsentrat asam lemak sangat efektif dilakukan dalam rangka meningkatkan mutu telur ayam dibandingkan dengan penggunaan konsetrat asam lemak secara langsung.

\section{Daftar pustaka}

Butarbutar, T.B. (2004). Fatty acid and cholesterol in egg : A Review. Southeast Asian J Trop Med Public Health, 35(4),1036 - 1038.

Cachaldora, P., Rebollar, P.G., Álvarez, C., Méndez, J., \& de Blas, J.C.(2005). Effect of conjugated linoleic acid, high-oleic sunflower oil and fish oil dietary supplementation on laying hen egg quality. Spanish Journal of Agricultural Research, 3(1), $74-82$.

Chamruspollert M. \& Sell, J.L., (1999). Transfer of dietary conjugated linoleic acid to egg yolks of chickens. Poultry Sci 78, 1138-1150.

Farrell, D. (1998). Enrichment of hen eggs with n-3 long-chain fatty acids and evaluation of enriched eggs in humans, Am J Clin Nutr, 68, 538 - 544.

Haris, W.S. (2004): Review : Fish oil supplementation : Evidence for health benefits. Cleveland Clinic Journal of Medicine, 71(3),208-219.

Jufri, Mahdi, Djayadisastra, Joshita, \& Maya, Ledy, (2009). Pembuatan mikroemulsi dari minyak buah merah. Majalah Ilmu Kefarmasian, 6 (1), 18 - 27.

Maulana, I.T. (2013). Pemisahan Asam Elaidat (trans-9-Octadecenoic Acid) dan Asam Lemak Jenuh Serta Peningkatan Kandungan EPA dan DHA dari Minyak Limbah Perusahaan Pengolahan Ikan.Tesis tidak dipublikasikan. Bandung: Sekolah Farmasi, Institut Teknologi Bandung.

Maulana, I.T., Sukrasno, \& Damayanti, S. (2014). Telaah Kandungan Asam Lemak dalam Minyak Ikan Indonesia. Jurnal Ilmu dan Teknologi Kelautan Tropis, 6(1), $121-130$ 
Maulana, I.T., Marcelina, Y., \& Sakti, E.R. (2015). Optimasi metode kompleksasi urea pada peningkatan nilai rasio EPA dan DHA terhadap asam lemak trans dalam minyak ikan limbah. Prosiding Seminar Penguatan Budaya Riset Jawa Barat

Mozaffarian, D., Katan, M. B., Ascherio, A., Stampfer, Meir J., \& Willett, W.C. (2006). Review article: Trans fatty acid and cardiovascular disease. $N$ Engl $J$ Med, 354, $1601-1611$.

Olaitan, B.P., Chen I-Ping, Norris, J., Feinn, R., Oluwatosin, O.M., \& Reichenberger, E.J. (2011). Inhibitory activities of omega-3 fatty acids and traditional african remedies on keloid fibroblasts. Wound, 23(4), 97 - 105.

Rose, E.L. \& Holub, B.J. (2006). Effects of a liquid egg product containing fish oil on selected cardiovascular disease risk factors: A randomized crossover trial, Food Research International Vol. 39, 910 - 916.

Scientific Advisory Commitee on Nutrition (SACN) (2007). Update on Trans Fatty Acids and Health, Edinburg UK: The Stasionary Office,. Hal $1-65$

Stender, S., \& Dyerberg, J. (2003): The Influence of Trans Fatty Acid on Health (Fourth Edition), Publ. No. 34, The Danish Nutrition Council. Hal 19 - 32. 